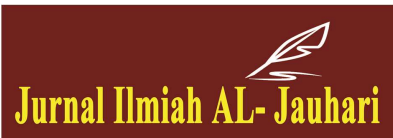

Jurnal Ilmiah ALoJauhari: Jurnal Studi Islam dan Interdisipliner

Volume 5 No 1, (April 2020): Halaman 47-76

ISSN (Print): 2541-3430, ISSN (Online): 2541-3449

Website: http://journal.iaingorontalo.ac.id/index.php/aj

\title{
Kepemimpinan Kepala Sekolah dalam Mengembangkan \\ Kegiatan Ekstrakurikuler Keagamaan di Sekolah Dasar Negeri 01 Lemito
}

\section{Isma Tangahu, Lisdawati Muda}

(Guru Sekolah Dasar Negeri 05 Lemito, Dosen IAIN Sultan Amai

Gorontalo)

Ismatangahu04@gmail.com, lisdawati02muda75@gmail.com

\begin{abstract}
This study aims to determine how the headmaster's leadership in the development of religious extracurricular activities in State Elementary School, Lemito. This type of research is a qualitative study with a sociological managerial approach.

The results showed: 1) religious extracurricular activities were carried out well in the form of: religious practices, reading and writing of the Koran and lightning boarding schools. 2) The nature of the principal's leadership in developing extracurricular activities is energetic in developing activities, intelligent controlling emotions and, able to motivate personal.

The principal's leadership in developing religious extracurricular activities should not be separated from the steps of development. Because even though the headmaster of the school is very good in his leadership character, if without developmental steps such as planning, organizing, communicating and monitoring in religious extracurricular activities the program will not be maximized.
\end{abstract}




\begin{abstract}
Abstrak
Penelitian ini bertujuan untuk mengetahui bagaimana kepemimpinan kepala sekolah dalam pengembangan kegiatan ekstrakurikuler keagamaan di SDN 01 Lemito Kabupaten Pohuwato. Jenis penelitian ini merupakan penelitian kualitatif dengan pendekatan pendekatan manajerial sosiologis.

Hasil penelitian menunjukkan: 1) kegiatan ekstrakurikuler keagamaan dijalankan secara baik dalam bentuk : praktik ibadah, baca tulis Alquran dan pesantren kilat. 2) Sifat kepemimpinan kepala Sekolah dalam mengembangkan kegiatan ekstrakurikuler bersifat energik dalam mengembangkan kegiatan, cerdas mengendalikan emosi dan, mampu memotivasi pribadi.

Sifat kepemimpinan kepala Sekolah dalam mengembangkan kegiatan ekstrakurikuler keagamaan sepatutnya tidak lepas dari langkah-langkah pengembangan. Sebab walaupun kepala Sekolah sangat baik sifat kepemimpinannya namun jika tanpa langkah pengembangan seperti perencanaan, pengorganisasian, komunikasi dan pengawasan dalam kegiatan ekstrakurikuler keagamaan maka program tersebut tidak akan maksimal.
\end{abstract}

Kata Kunci: Kepemimpinan, Kepala Sekolah, Ekstrakurikuler, Keagamaan

\title{
Pendahuluan
}

Sekolah sebagai penyelenggara pendidikan formal, pada prinsipnya bertujuan untuk membentuk manusia yang berkepribadian dan mengembangkan intelektual peserta didik dalam rangka mencerdaskan kehidupan bangsa. Melalui pendidikan yang diselenggarakan, kelak akan lahir generasi penerus yang menjadi penentu maju tidaknya peradaban bangsa ini. Itu sebabnya, pendidikan menjadi satu hal yang sangat krusial dan penting bagi nasib bangsa Indonesia kedepan.

Pendidikan merupakan upaya sadar dan terencana yang dilakukan oleh guru untuk mengembangkan segenap potensi peserta didiknya secara optimal. Potensi ini mencakup potensi jasmani dan rohani sehingga melalui pendidikan seorang peserta didik dapat mengoptimalkan pertumbuhan fisiknya agar memiliki kesiapan untuk melakukan tugas-tugas perkembangannya dan dapat mengoptimalkan perkembangan rohaninya agar dengan totalitas pertumbuhan fisik dan 
perkembangan psikisnya secara serasi dan harmoni, dia dapat menjalankan tugas hidupnya dalam seluruh aspeknya, baik sebagai anggota masyarakat, sebagai individu maupun sebagai makhluk Tuhan Yang Maha Esa. ${ }^{1}$

Khusus untuk kegiatan Ekstrakurikuler, menjadi bagian yang sangat penting diperhatikan olehkepala sekolah dalam rangkamembantu pengembangan peserta didik. Karena pada prinsipnya kegiatan Ekstrakurikuler adalah kegiatan pendidikan di luar mata pelajaran dan pelayanan konseling untuk memenuhi kebutuhan, potensi, bakat dan minat siswa melalui kegiatan yang secara khusus diselenggarakan oleh pendidik dan atau tenaga kependidikan yang berkemampuan dan berkewenangan di sekolah.

Karena itu, kedudukan kepala sekolah tidak bisa dipegang oleh sembarang orang. Kepala sekolah harus memenuhi kompetensi kepemimpinan dalam menjalankan perannya mengepalai satuan pendidikan. Perilaku kepemimpinan merupakan tindakan-tindakan spesifik seorang dalam mengarahkan dan mengkoordinasikan kerja anggota kelompok $^{2}$. Sebagai pemimpin yang mempunyai pengaruh, ia berusaha agar nasehat, saran, dan jika perlu perintahnya diikuti oleh seluruh unsur pendidikan di sekolah. Dengan demikian ia dapat mengadakan perubahan-perubahan dalam cara berfikir, sikap, tingkah laku yang dipimpinnya. Dengan kelebihan yang dimilikinya yaitu kelebihan dalam hal kepemimpinan, ia membantu guru-guru mengembangkan kegiatan di luar jam mata pelajaran khususnya yang berkenaan dengan ekstrakurikuler.

Kegiatan ekstrakurikuler biasanya dilakukan dalam rangka merespons kebutuhan peserta didik dan menyalurkan serta mengembangkan hobi, minat dan bakat peserta didik. Setiap peserta didik tidak harus mengikuti semua

Kegiatan ekstrakurikuler di sekolah, tetapi cukup memilih kegiatan ekstrakurikuler yang dapat mengembangkan kemampuan dirinya. Contoh kegiatan ekstrakurikuler tersebut yaitu: OSIS (Organisasi Siswa Intra Sekolah), Rohis (Rohani Islam), Kelompok Olahraga (Karate, silat, basket, futsal, sepak bola, volley ball), pramuka, kelompok seni

\footnotetext{
${ }^{1}$ Ardy Wiyani Novan, Psikologi Perkembangan Anak Usia Dini, (Yogyakarta: Gava Media, 2014) h. 26

${ }^{2}$ Danim, Sudarwan, Kepemimpinan Pendidikan, Kepemimpinan Jenius, Etika, Perilaku Motivasional, dan Mitos. (Bandung: Alfabeta, 2010) h. 41
} 
(teater, tari, marawis, angklung dan degung). Melalui kegiatan ekstrakurikuler inilah peserta didik dibina dan dikembangkan agar menjadi manusia yang diharapkan Mampu memotivasi sesuai dengan tujuan pendidikan. ${ }^{3}$

Oleh karena itu, kegiatan pengembangan diri pada bidang keagamaan khususnya dibidang peningkatan bacaan Al-Qur'an dan kesenian Islami peserta didik harus diadakan, karena kegiatan ekstrakurikuler ini dapat memotivasi peserta didik dalam menunjukkan bakat dan minatnya. Pada dasarnya kegiatan ekstrakurikuler keagamaan dilakukan untuk menggali potensi peserta didik dalam bidang tertentu. Untuk tujuan ekstrakurikuler adalah mengembangkan potensi peserta didik sesuai dengan bakat dan kemampuannya dan disesuaikan dengan kondisi peserta didik.

Sehubungan dengan hal itu, kegiatan ekstrakurikuler yang dilaksanakan di masing-masing sekolah maupun madrasah berbeda-beda. Kegiatan ini memberikan kesempatan kepada peserta didik untuk mengembangkan kemampuan yang telah dimiliki masing-masing peserta didik. Dalam bidang keagamaan misalnya, terdapat berbagai kegiatan ekstrakurikuler seperti: Murrotal, Tilawah dan Rebana. Kegiatan ekstrakurikuler murrotal dan tilawah ini tidak hanya mengajarkan cara membaca al-Qur'an dengan tajwid saja melainkan juga dengan irama lagu al-Qur'an. Untuk itu selain belajar membaca al-Qur'an peserta didik juga belajar bagaimana melafadzkan ayat-ayat al-Qur'an dengan indah dan disertai dengan lagu al-Qur'an.

Dari uraian di atas dapat dilihat betapa pentingnya pelaksanaan kegiatan ekstrakurikuler keagamaan. Selain dapat mengangkat nama baik sekolah dalam berbagai event atau lomba yang diikuti, kegiatan ekstrakurikuler keagaman ini dapat pula meningkatkan kesadaran siswa dalam memahami nilai-nilai agama. Kegiatan ekstra kurikuler keagamaan merupakan sebuah alternatif dalam pembentukan karakter siswa. Dimana Kegiatan ektrakurikuler adalah kegiatan yang menunjang kegiatan intrakurikuler yang pelaksanaannya diluar jam kegiatan intrakurikuler. Kegiatan ekstrakurikuler keagamaan adalah upaya pemantapan dan pensifatan nilai-nilai dan norma serta pengembangan kepribadian, bakat dan minat peserta didik yang 2014), h. 46.

${ }^{3}$ Badrudin, Dasar-dasar Manajemen Cetakan kedua, (Bandung: Alfabeta,

50 | Isma Tangahu 
dilaksanakan di luar jam intrakurikuler dalam bentuk tatap muka atau non tatap muka.

Untuk mewujudkan kegiatan ekstrakurikuler keagamaan maka tidak bisa dilepaskan dari kepemimpinan kepala sekolah. Kepala sekolah merupakan figur sentral dalam pencapaian tujuan pendidikan, satu diantaranya adalah berjalannya kegiatan ekstrakurikuler keagamaan. Karenanya kepala sekolah diharapkan mampu menterjemahkan peran dan fungsinya dalam kapasitasnya yang kompleks. Suksesnya kepemimpinan seorang kepala sekolah ditandai oleh adanya sikap kepatuhan dari bawahannya dalam menjalankan visi dan misinya. ${ }^{4}$

Untuk menjalankan peran dan fungsinya, kepala sekolah (pemimpin) harus memiliki sifat kepemimpinan yang mengayomi atau human oriented tanpa mengesampingkan hasil kerja bawahannya (task oriented). Hubungan antara kepala sekolah dengan bawahannya harus menunjukkan sebuah realitas mutualisme, kepala sekolah harus memperlakukan bawahan layaknya manusia bukan robot agar apa yang menjadi tujuan dilaksanakannya kegiatan ekstrakurikuler itu tercapai.

Dalam mengelola sekolah, kepala sekolah bisa memilih teori dan menerapkan sifat kepemimpinan yang tepat dari beberapa sifat kepemimpinan yang ada sesuai dengan karakter pribadi, dan kondisi organisasi sekolah yang dipimpin. Yang penting kepala sekolah, harus bisa menampilkan peranan kepemimpinan yang baik. Kepemimpinan seorang kepala sekolah dimaksudkan untuk membangun kerja sama yang baik diantara semua anggota agar bisa mewujudkan tujuan organisasi sekolah secara optimal. Bukan tidak mungkin, dengan memilih sifat kepemimpinan yang tepat seorang kepala akan mampu menciptakan generasi bangsa yang berkarakter kuat melalui kegiatan ekstrakurikuler keagamaan. ${ }^{5}$

Seperti halnya apa yang terjadi di SDN 01 Lemito Kabupten Pohuwato Propinsi Gorontalo. Dalam pantauan awal di sekolah tersebut kegiatan ekstrakurikuler keagamaan berjalan dengan baik. Dalam setiap pekannya, Sekolah

\footnotetext{
${ }^{4}$ Siagian, P. Sondang, Pemimpin dan Kepemimpinan Kepala Sekolah. (Jakarta: Gunung Agung, 2001) hal, 65

${ }^{5}$ Buku Panduan Peraturan Pendidikan Nasional, Undang-Undang No. 14 Tahun 2005 tentang Guru dan Dosen Pasal 1 Butir 4, Pasal 7 Ayat 1, (Jakarta, Balai Pustaka, 2005) hal. 91
} 
tersebut tidak pernah sepi oleh hiruk pikuk siswa yang mengikuti ragam kegiatan keagamaan. Di samping proses pembelajaran yang berjalan normal, di sela-sela waktu luang, di hampir setiap ruang dan tempat tersisa penulis menyaksikan seluruh elemen sekolah nampak serius menikmati berbagai macam aktifitas ekstrakurikuler yang disuguhkan siswanya. Bukan hanya di dalam lingkungan sekolah, beberapa kelompok siswa SDN 01 mengikuti kegiatan ekstrakurikuler yang mereka selenggarakan di banyak tempat. Di sanggar, Mesjid dan Taman Pengajian, keterlibatan anak dalam kegiatan di tempat tersebut menunjukan betapa kegiatan ekstrakurikuler SDN 01 dibawah kepemimpinan kepala sekolahnya berhasil terselenggara dengan sangat baik.

Dari latar belakang yang dipaparkan di atas menjadi salah satu alasan penting penulis untuk melakukan penelitian dengan tema "Sifat Kepemimpinan Kepala Sekolah dalam Mengembangkan Kegiatan Ekstrakurikuler Keagamaan di Sekolah Dasar Negeri 01 Lemito Kabupaten Pohuwato"

\section{Konsep Dasar Kepemimpinan Kepala Sekolah}

Pemimpin adalah seseorang yang mempunyai kemampuan untuk mempengaruhi perilaku orang lain dalam kerjanya dengan menggunakan kekuasaan. Kekuasaan adalah kemampuan untuk mengarahkan dan mempengaruhi bawahan sehubungan dengan tugas-tugas yang harus dilaksanakannya. Menurut Stoner, semakin banyak jumlah sumber kekuasaan yang tersedia bagi pemimpin, akan makin besar potensi kepemimpinan yang efektif. Namun itu berlaku ketika seorang pemimpin memiliki karakter kuat, tegas, dan berjiwa pembelajar. Sebaliknya, kekuasaan yang besar di tangan pemimpin yang lemah karakter, pengetahuan dan keterampilan, hanya akan membawa lembaga pendidikan pada ujung kebangkrutan dan tumpukan masalah yang tidak terselesaikan dengan baik, bahkan menimbulkan konflik internal. $^{6}$

Kepemimpinan merupakan salah satu faktor yang sangat penting dalam suatu organisai karena sebagian besar keberhasilan dan kegagalan suatu organisasi ditentukan oleh kepemimpinan dalam organisasi tersebut. Pentingnya

\footnotetext{
${ }^{6}$ Fattah, Kepemimpinan Sebuah Keniscayaan, (Jakarta: Titian Ilmu, 2004) hal. 88

52 | Isma Tangahu
} 
kepemimpinan seperti yang dikemukakan oleh James M. Black pada Manajemem: a Guide to Executive Command dalam Sadili Samsudin yang dimaksud dengan "Kepemimpinan adalah kemampuan meyakinkan dan menggerakkan orang lain agar mau bekerja sama di bawah kepemimpinannya

Wahjosumidjo mengartikan bahwa: "Kepala sekolah adalah seorang tenaga fungsional guru yang diberi tugas untuk memimpin suatu sekolah di mana diselenggarakan proses belajar mengajar, atau tempat di mana terjadi interaksi antara guru yang memberi pelajaran dan murid yang menerima pelajaran. Dengan kata lain, "Kepala sekolah adalah seorang guru (jabatan fungsional) yang diangkat untuk menduduki jabatan struktural (kepala sekolah) di sekolah"7

Berdasarkan beberapa pengertian di atas dapat disimpulkan bahwa kepala sekolah adalah sorang guru yang mempunyai kemampuan untuk memimpin segala sumber daya yang ada pada suatu sekolah sehingga dapat didayagunakan secara maksimal untuk mencapai tujuan bersama.

Dalam kelompok masyarakat selalu muncul seorang pemimpin yang dapat mempegaruhi dan mengarahkan prilaku anggota masyarakat, ke arah tujuan tertentu dengan demikian, pemimipin di anggap mewakili aspirasi masyarakat, pemimpin dapat memperjuangkan kepentingan anggota, dan pemimpin dapat mewujudkan harapan sebagian besar orang. ${ }^{8}$ Selain beberapa faktor yang mendasari lahirnya pemimpin, pada kenyataan pemimipin mempunyai kecerdasan dan wawasan yang lebih luas di bandingkan dengan rata- rata pengikutnya, sehingga wajar kehadiran pemimpin sangat di rindukan untuk mengatasi berbagai masalah yang di hadapi oleh anggota masyarakat. ${ }^{9}$

Dalam usaha untuk memenuhi harapan, pemimpin menggunakan kemampuan dan kecerdasannya memamfaatkan lingkungan dan potensi yang ada pada organisasi. Dengan kata lain pemimpin berusaha melibatkan anggota organisasi untuk mencapai tujuan. Kemampuan untuk menggerakan, mengarahkan dan mempengaruhi anggota organisasi sebagai upaya untuk mencapai tujuan

\footnotetext{
${ }^{7}$ Wahjosumidjo, Kepemimpinan Kepala Sekolah Tinjauan Teoritik dan. Permasalahannya, (Jakarta: Rajawali Pers., 2002) hal. 83

${ }^{8}$ Wahyudi., Kepemimpinan Kepala Sekolah dalam Organisasi Pembelajaran. (Bandung: Alfabeta, 2009) hal. 119

${ }^{9}$ Ibid, hal. 121
} 
organisasi sebagai wujud kepemimpinannya. kesanggupan mempegaruhi prilaku orang lain ke arah tujuan tertentu sebagai indikator keberhasilan seorang pemimpin .

Definisi kepemimpinan terus mengalami perubahan sesuai dengan peran yang di jalankan, kemampuan untuk memberdayakan (empowering) bawahan/anggota sehingga timbul inisiatif untuk berkreasi dalam bekerja dan hasilnya lebih bermakna bagi organisasi dengan sekali-kali pemimpin mengarahkan, menggerakan dan mempengaruhi anggota inisiatif harus di respon sehingga dapat mendorong timbulnya sikap mandiri dalam bekerja dan berani mengambil keputusan dalam rangka percepatan pencapaian tujuan organisasi. Dengan demikian, kepemimpinan dapat diartikan sebagai kemampuan seorang dalam menggerakan, mengarahkan, sekaligus mempengaruhi pola pikir, cara kerja setiap anggota agar bersikap mandiri dalam bekerja terutama dalam pengambilan keputusan untuk kepentingan percepatan pencapaian tujuan yang telah di tetapkan. ${ }^{10}$

\section{Kajian Pengembangan Kegiatan Ekstrakurikuler Keagamaan}

Sekolah sebagai lembaga pendidikan mempunyai peranan yang sangat menentukan dalam rangka peningkatan kualitas sumber daya manusia, terutama bagi perkembangan dan perwujudan diri individu dalam pembangunan bangsa dan negara. Kemajuan suatu bangsa tergantung kepada cara kebudayaan bangsa tersebut mengenali, menghargai dan memanfaatkan sumber daya manusia dan dalam hal ini berkaitan erat dengan kualitas pendidikan yang diberikan kepada masyarakatnya, yaitu kepada peserta didik.

Sebagai lembaga penyelenggara pendidikan, sekolah tentu saja merupakan bagian dari organisasi. Sekolah adalah bentuk organisasi pendidikan yang didalamnya terdapat penyelenggra, dan salah salah satu penyelenggara yang dimaksud adalah kepala sekolah. Ia memiliki sejumlah tugas dan tanggung jawab yang cukup berat. Untuk bisa menjalankan fungsinya secara optimal, kepala sekolah perlu menerapkan sifat kepemimpinan yang tepat. Peranan utama kepemimpinan kepala sekolah adalah sumber energi utama ketercapaian tujuan pendidikan, ya'ni semata untuk mencerdaskan kehidupan bangsa. Untuk mencapai semua itu

${ }^{10}$ Ibid, hal. 120 
maka kualitas kepemimpinan merupakan sarana utama yang sangat menentukan.

Pada sistem organisasi sekolah, kepala sekolah merupakan pemimpin bagi masyarakat sekolah lainnya baik guru, karyawan, dan siswa. Sebagai pemimpin, maka perilaku kepala sekolah akan berpengaruh terhadap perilaku masyarakat sekolah lainnya. Perilaku positif dari kepala sekolah akan memacu guru dan karyawan memberikan perilaku yang positif dalam mencapai tujuan pendidikan. Sebaliknya, perilaku kepala sekolah yang negatif merupakan awal dari gagalnya penyelenggaran pendidikan di sekolah tersebut. Peran kepemimpinan kepala sekolah menjadi sangat penting bagi terselenggaranya pendidikan. ${ }^{11}$

Bila ditelaah dari perkembangan teori, ada banyak teori kepemimpinan yang bisa dicermati untuk mengkaji masalah kepemimpinan. Teori kepemimpinan yang pertamatama dikembangkan adalah teori sifat atau trait theory. Pada dasarnya teori sifat memandang bahwa keefektifan kepemimpinan itu bertolak dari sifat-sifat atau karakter yang dimiliki seseorang. Keberhasilan kepemimpinan itu sebagian besar ditentukan oleh sifat-sifat kepribadian tertentu, misalnya harga diri, prakarsa, kecerdasan, kelancaran berbahasa, kreatifitas termasuk ciri-ciri fisik yang dimiliki seseorang. Pemimpin dikatakan efektif bila memiliki sifatsifat kepribadian yang baik. Sebaliknya, pemimpin dikatakan tidak efektif bila tidak menunjukkan sifat-sifat kepribadian yang baik

Kepala sekolah sebagai pemimpin pendidikan perannya sangat penting untuk membantu guru dan muridnya. Didalam kepemimpinannya kepala sekolah harus dapat memahami, mengatasi dan memperbaiki kekurangan-kekurangan yang terjadi di lingkunagn sekolah. ${ }^{12}$ Selain sebagai pemimpin, kepala sekolah juga dituntut memiliki kemampuan mengembangkan hal terkait dengan kegiatan belajar siswa, baik yang intrakurikuler maupun ekstrakurikuler.

Ekstrakurikuler keagamaan yang penulis maksudkan disini adalah program ekstrakurikuler keagamaan yang wajib dan rutin dilaksanakan oleh seluruh warga madrasah. focus tujuan pembahasan hanya pada program ekstrakurikuler 2014) hal. 21

${ }^{11} \mathrm{Ibid}, 43$

${ }^{12}$ Imam Cahyo, Kepemipinan Kepala sekolah, (Jakarta: Pustaka Abadi, Jurnal Ilmiah AL-Jauhari Vol. 5 No. 1 (2020): 47-76 
keagamaan yang bersifat rutin dan wajib ini membuat peneliti tertarik untuk meneliti bagaimanakah konstribusi yang diberikan bagi pembentukan moral siswa dalam mengikuti program ekstrakurikuler keagamaan tersebut, serta keefektifan adanya program tersebut tujuannya dalam membimbing siswa untuk membentuk moralitas yang baik.

Kegiatan ekstrakurikuler sendiri menurut Suharsimi Arikunto diatas dimaknainya sama dengan kegiatan tambahan, diluar struktur program yang ada pada umumnya merupakan kegiatan pilihan. ${ }^{13}$ Menurut Direktorat Pendidikan menengah Kejuruan definisi dari kegiatan ekstrakurikuler adalah kegiatan yang dilakukan diluar jam pelajaran tatap muka, dilaksanakan di sekolah atau luar sekolah agar lebih memperkaya dan memperluas wawasan pengetahuan dan kemampuan yang telah dipelajari dari berbagai mata pelajaran dan kurikulum. Berdasarkan uraian di atas dapat disimpulkan kegiatan ekstrakurikuler adalah kegiatan tambahan diluar struktur program yang dilakasanakan di luar jam pelajaran biasa agar memperkaya dan memperluas wawasan pengetahuan dan kemampuan siswa. ${ }^{14}$

Kegiatan ekstrakurikuler keberadaannya sering dibedakan dari kegiatan intrakurikuler dipemimpin banyak pihak sebagai usaha pendidikan yang melibatkan proses penypemimpinran nilai-nilai, bahkan sampai pada internalisasi nilai-nilai. Pada beberpa sekolah yang memanfaatkan pembelajaran di luar kelas sebagai wahana pengembangan pendidikan, kegiatan ekstrakurikuler muncul sebagi program unggulan tersendiri lembaga pendidikan. Program ekstrakurikuler yang, merupakan seperangkat pengalaman belajar memiliki nilai-nilai manfaat bagi pembentukan kepribadian peserta didik.

Program ekstrakurikuler keagamaan adalah berbagai program kegiatan yang diselenggarakan di luar jam pelajaran dalam rangka memberikan arahan bagi peserta didik untuk dapat mengamalkan ajaran agama yang diperolehnya melalui kegiatan belajar dikelas serta untuk mendorong pembentukan pribadi peserta didik dan penanaman nilai-nilai agama dan akhlakul karimah peserta didik. Tujuannya adalah

\footnotetext{
${ }^{13}$ Suharsimi Arikunto, Organisasi dan Administrasi Pendidikan Teknologi dan Kejuruan, Eidisi ke- 3 (Jakarta : P2LPTK, 1993), hal. 27

${ }^{14}$ Suryosubroto, Proses Belajar Mengajar di Sekolah,(Jakarta: PT Rineka Cipta, 2002), hal. 271.
}

56 | Isma Tangahu 
membentuk manusia yang terpelajar dan bertaqwa kepada Allah swt, ${ }^{15}$

\section{Kegiatan Ekstrakurikuler Keagamaan di Sekolah}

Ekstrakurikuler adalah wahana pengembangan pribadi peserta didik melalui berbagai aktivitas, baik yang terkait langsung maupun tidak langsung dengan materi kurikulum. Disamping itu, kegiatan ekstrakurikuler merupakan kegiatan yang bernilai tambah sebagai pendamping intrakurikuler dan agar peserta didik mempunyai nilai plus selain pelajaran akademis. Hal ini juga disesuaikan dengan kondisi sekolah, terutama dengan sarana dan prasarana yang tersedia, sehingga setiap sekolah mempunyai kegiatan ekstrakurikuler yang berbeda-beda, dan kegiatan ini dilaksanakan dalam rangka meningkatkan sumber daya yang berkualitas. ${ }^{16}$

Sekolah Dasar Negeri 01 Lemito adalah lembaga pendidikan yang sifatnya formal dimana pendiriannya dilakukan oleh negara dengan tujuan untuk memberikan pengajaran, mengelola, dan mendidik para murid melalui bimbingan yang diberikan oleh para pendidik atau guru. Bentuk pelaksanaannya berupa kegiatan intrakulikuler dan ekstrakulikuler.

Khusus untuk kegiatan ekstrakurikuler, bagi SDN 01 Lemito, dirasa penting untuk dikembangkan. Menurut Kepala sekolah kegiatan tersebut disamping untuk mempercepat pemahaman siswa terhadap materi pelajaran yang mereka peroleh di jam belajar juga dimaksudkan untuk mengakomodasi kebutuhan non akademik. Kegiatan ekstrakurikuler mengakomodasi kebutuhan perkembangan tersebut di bidang non akademik, sehingga siswa sadar akan potensi yang ada dalam dirinya dan mau terus berjuang menekuni kegiatan tersebut. Jika kegiatan ekstrakulikuler dapat ditekuni dengan sungguh-sungguh, tidak menutup kemungkinan peserta didik tersebut mendapatkan prestasi atas jerih payahnya" 17

\footnotetext{
${ }^{15}$ Departemen Agama RI, Panduan Kegiatan Ekstrakurikuler Pendidikan Agama Islam, (Jakarta: Direktorat Jenderal Kelembagaan Agama Islam, 2005), hal. 9.

${ }^{16}$ Popi Sopiatin, Manajemen Belajar Berbasis Kepuasan Siswa, (Bogor: Ghalih Indonesia: 2014) hal. 99)

${ }^{17}$ Yunizar Tangahu, Kepala SDN 01 Lemito Kabupaten Pohuwato. Wawancara : 12 Agustus 2019
} 
Ekstrakurikuler merupakan kegiatan tambahan di SDN 01 Lemito kabupaten Pohuwato yang bisa dipilih oleh siswa sesuai bakat dan minatnya. Kegiatan ini memiliki banyak manfaat. Ekstrakurikuler sebagai media untuk mengembangkan potensi dan bakat siswa. Siswa yang terlibat pada kegiatan ekstrakurlikuler dapat mengasah bakat yang dimilikinya secara bertahap. Selain itu, juga dapat menjadi media penggali potensi untuk siswa yang belum menyadari apa bakat yang dimilikinya.

"Sekolah ini memberi keleluasaan kepada siswa untuk memilih apa saja kegiatan yang diminati. Biasanya siswa cenderung mengambil kegiatan yang memang mempunyai latarbelakang bakat yang mereka punyai" 18

Sebagai Lembaga Pendidikan formal yang memanfaatkan pembelajaran di luar kelas, SDN 01 Lemito, dalam pantauan penulis, kegiatan ekstrakurikuler bagi mereka sengaja dimunculkan sebagi program unggulan tersendiri. Hal ini sebagaimana yang diutarakan oleh Guru Kelas V SDN 01 Lemito berikut:

"Bagi kami, Program ekstrakurikuler, khususnya bidang keagamaan merupakan seperangkat pengalaman belajar memiliki nilai-nilai manfaat bagi pembentukan kepribadian peserta didik. Itu sebabnya kegiatan ini kami menjadikan ekstrakuriler keagamaan sebagai program unggulan SDN 01 Lemito" 19

Program ekstrakurikuler keagamaan memberikan arahan bagi peserta didik untuk dapat mengamalkan ajaran agama yang diperolehnya melalui kegiatan belajar dikelas serta untuk mendorong pembentukan pribadi peserta didik dan penanaman nilai-nilai agama dan akhlakul karimah peserta didik. Tujuannya adalah membentuk manusia yang terpelajar dan bertaqwa kepada Allah SWT.

Selama melakukan observasi di SDN 01 Lemito penulis menemukan bahwa ekstrakurikuler keagamaan di sekolah tersebut bersifat rutin dan mencakup kewajiban partisipasi bagi seluruh siswanya. Program ekstrakurikuler keagamaan dikemas melalui shalat berjamaah, baca tuis alqur'an dan pesantren kilat. Pelaksanaan program

\footnotetext{
${ }^{18}$ Sopiah A. Harun, Guru Kelas VI SDN 01 Lemito Kabupaten Pohuwato. Wawancara: 12 Agustus 2019

${ }^{19}$ Yeny Puhi, Guru Kelas V SDN 01 Lemito Kabupaten Pohuwato. Wawancara : 12 Agustus 2019

58 | Isma Tangahu
} 
ekstrakurikuler keagamaan di SDN 01 Lemito berbeda variasinya dengan beberapa sekolah pada umumnya hal ini terjadi karena ditentukan oleh kemampuan guru, siswa, dan kemampuan sekolahnya.

"Kebetulan di SDN 01 ini ada beberapa guru yang memang sangat aktif dalam kegiatan kemasyarakatan sehingga pengalaman-pengalaman yang diperoleh diluar sana kemudian dipraktekan kepada siswa didik disini melalui kegiatan ekstrakuriler keagamaan" 20

Dalam setiap program kegiatan yang dilakukan, tidak terlepas dari aspek tujuan. Begitu pula program ekstrakurikuler keagamaan yang dilaksanakan di SDN 01 Lemito kabupten Pohuwato. Program ekstrakurikuler di sekolah itu bertujuan untuk menciptakan generasi yang beriman dan bertaqwa kepada Allah swt sebagaimana yang diamanatkan oleh pendidikan Islam. Tidak hanya secara umum, tujuan dilaksanakannya program ekstrakurikuler secara khsusus untuk memperdalam pengetahuan siswa mengenai materi yang diperoleh di kelas agar melahirkan generasi yang utuh pembinaannya. "Secara umum, kegiatan ekstrakurikuler keagamaan bertujuan agar peserta didik menjadi insan kamil. Selain itu pula supaya mereka memiliki memiliki ahlak yang baik. Secara khusus program ekstrakurikuler keagamaan ini bertujuan memperdalam pengetahuan siswa mengenai materi yang diperoleh di kelas, hubungan antar mata pelajaran keimanan dan ketaqwaan, serta sebagai upaya, melengkapi pembinaan manusia seutuhnya" 21

Sebagaimana yang disampaikan oleh guru Pendidikan Agama Islam di atas, untuk mencapai tujuan dari pendidikan Islam, maka guru tidak hanya bisa mengandalkan pada kegiatan proses belajar mengajar di kelas saja yang minim pertemuannya. Pendidikan Islam setelah dipelajari dan dipahami dibutuhkan tindak lanjut berupa pengamalan atau praktek dalam kehidupan seharihari.

"Manfaat program ekstrakurikuler keagamaan sendiri adalah untuk memberikan pengalaman

\footnotetext{
${ }^{20}$ Misran Nani, Guru Pendidikan Agama Islam SDN 01 Lemito Kabupaten Pohuwato. Wawancara: 13 Agustus 2019

${ }^{21}$ Misran Nani, Guru Pendidikan Agama Islam SDN 01 Lemito Kabupaten Pohuwato. Wawancara : 13 Agustus 2019
} 
peserta didik dalam menjalankan agamanya. Dan fungsi tersebut sangatlah bervariasi tetapi pada umumnya adalah sebagai langkah pengembangan instusi sekolah, dan wadah pengembangan kecerdasan, kreatifitas speserta didik" ${ }^{22}$

\section{Bentuk Kegiatan Ekstrakurikuler Keagamaan}

Hasil pentauan langsung di lokasi penelitian menunjukkan bahwa kegiatan ekstrakurikuler di SDN 01 Lemito kabupaten Pohuwato tidak hanya terdiri atas satu bentuk saja. Bentuk-bentuk kegiatan ekstrakurikuler begitu bervariasi.

"Di sini banyak macam kegiatan ekstrakurikuler yang bernuansa keagamaan. Tentu saja hal ini disetujui oleh banyak pihak. Seluruh unsur di SDN 01 Lemito, baik itu kepala sekolah, guru dan orang tua siswa bersepakat bahwa kegiatan ekstrakurikuler yang demikian banyak harus digalakkan. Ini dimaksudkan agar peserta didik mampu belajar untuk memecahkan masalah-masalah yang berkembang dilingkungannya, dengan tetap tidak melupakan masalah-masalah global yang tentu saja harus diketahui oleh peserta didik." 23

Adapun beberapa bentuk program ekstrakurikuler Keagamaan di sekolah, diantaranya adalah:

\section{a. Praktek Ibadah}

Ketika bel berbunyi tanda ishoma (istirahat, sholat dan makan) siswa anak langsung bergegas ke bagian belakang sekolah untuk mengambil air wudhu. Mereka berbaris membentuk antrian di depan setiap kran air. Ada lebih 10 kran tersedia yang mengucurkan airnya untuk wudhu bagi 123 siswa setiap harinya. Beberapa guru mendampingi siswa berwudhu untuk melihat dan memberikan bimbingan kepada siswa yang tatacara berwudhunya belum tertib.

Bila ada siswa yang wudhunya belum berurutan atau belum tertib tata caranya, maka guru tersebut akan

\footnotetext{
${ }^{22}$ Misran Nani, Guru Pendidikan Agama Islam SDN 01 Lemito Kabupaten Pohuwato. Wawancara: 15 Agustus 2019

${ }^{23}$ Elis. Dj. Abdullah, Guru Kelas IV SDN 01 Lemito Kabupaten Pohuwato. Wawancara : 15 Agustus 2019 
menegur dan memberikan contoh atau arahan cara berwudhu yang benar. Setelah selesai berwudhu mereka akan langsung menuju kelas masing-masung guna melaksanakan shalat berjamaah. Dimana setiap siswa lakilaki akan mendapatkan jadwal untuk menjadi muadzin dan imam. Sedangkan wali kelas dan guru pendamping memonitor kegiatan siswa dari belakang sambil mengoreksi bacaan dan gerakan shalat siswa. Bacaan shalat dilafadzkan secara jahr sebagai pembelajaran dan hafalan siswa terutama kelas rendah (1-3). Untuk kelas tinggi (4-6) beberapa siswa laki-lakinya yang bersuara lantang dan bagus mendapatkan jadwal secara bergiliran untuk mengumandangkan adzan dengan pengeras suara.

Inilah proses pembelajaran ibadah shalat yang dilaksanakan di sekolah. Melalui kegiatan keagamaan praktek ibadah secara langsung dapat menanamkan disiplin menjalankan shalat di awal waktu dan berjamaah.

"Kami berprinsip bahwa pondasi yang kuat akan mengokohkan bangunan setinggi apapun. Begitu juga halnya dengan pondasi agama yang ditanamkan dan dibiasakan sejak dini di sekolah. Insya Allah mereka akan tumbuh berkembang dewasa menjadi manusia sholeh dan sholehah yang cinta Allah dan agamanya" 24

Kegiatan pelatihan ketrampilan pengamalan ibadah ini bertujuan untuk menjadikan peserta didik sebagai muslim yang disamping berilmu juga mampu mengamalkan ajaran agamanya dalam kehidupan sehari-hari.

"Praktik ibadah berupa tata cara berwudhu dan sholat bejamaah yang kami selenggarakan setiap hari bertujuan untuk memperdalam wawasan peserta didik tentang makna-makna yang terkandung dalam ibadah-ibadah yang diperintahkan agama, sehingga mampu mengimplementasikan nilai-nilai ajaran didalamnya dalam kehidupan sehari-hari",25

Hal serupa juga disampaikan oleh salah satu guru SDN 01 Lemito tentang tujuan dilaksanakannya kegiatan

\footnotetext{
${ }^{24}$ Yunizar Tangahu, Kepala SDN 01 Lemito Kabupaten Pohuwato. Wawancara : 16 Agustus 2019

${ }^{25}$ Hirna Giasi, Guru Kelas I SDN 01 Lemito Kabupaten Pohuwato. Wawancara : 16 Agustus 2019
} 
ekstrakurikuler praktik beribadah.

"Esktrakurikuler praktik beribadah adalah rangkaian praktik di luar jam belajar dalam rangka menumbuhkan sikap mental jujur, ikhlas, sadar, tegas dan berani dalam menjalankan tanggungjawabnya, baik secara individual maupun social. Melatih ketrampilan dan kedisiplinan peserta didik dalam menjalankan ritual keagamaannya" 26

Tujuan Kagiatan Ekstrakurikuler keagamaan di SDN Lemito untuk meningkatkan keimanan, ketakwaan dan akhlak mulia peserta didik. Selanjutnya ia juga mampu meningkatkan pemahaman, penghayatan dan pengamalan ajaran agama dalam kehidupan sehari-hari peserta didik. Di samping menumbuhkan keingintahuan peserta didik terhadap hal-hal baru dan mendorong mereka untuk lebih bereksplorasi dalam membangun kepercayaan diri, praktek ibadah juga mendorong dan membiasakan peserta didik dalam pembinaan akhlak mulia sesuai dengan nilai-nilai agama, menumbuh kembangkan potensi, minat dan bakat yang dimiliki peserta didik berkaitan dengan kegiatan keagamaan. Selain itu praktek ibadah memfasilitasi peserta didik serta memberikan kesempatan untuk berlatih, meningkatkan kedisiplinan diri dan pemanfaatan waktu saat kumandang adzan dan masa sholat tiba.

Kegiatan ekstrakurikuler keagamaan yang diselenggarakan SDN 01 Lemito diharapkan bermanfaat bagi peserta didik, pengembangan kurikulum, sekolah, maupun bagi masyarakat luas.

"Secara terinci manfaat kegiatan ekstrakurikuler memberikan kesempatan kepada peserta didik bagi pemantapan ketertarikan dan keterikatannya terhadap nilai-nilai agama yang dianutnya. Memberikan kesempatan kepada peserta didik dalam melatih dan mengamalkan nilai-nilai agama yang diterima di bangku kelas. Memberikan kesempatan kepada peserta didik berlatih secara praktis dalam hal kepemimpinan, persahabatan, kerjasama, dan kemandirian Membangun semangat dan mentalitas

\footnotetext{
${ }^{26}$ Asrin Umar, Guru Kelas II SDN 01 Lemito Kabupaten Pohuwato. Wawancara : 16 Agustus 2019

62 | Isma Tangahu
} 
belajar dan bersekolah"27

b. Baca Tulis Al-Qur'an

SDN 01 Lemito Kabupten Pohuwato merupakan sekolah umum yang tidak secara khusus diorganisir memberi muatan keislaman kepada siswanya, namun lembaga ini tidak mengabaikan juga nilai-nilai keislaman. Melalui kegiatan ekstrakurikuler sekolah tetap memfokuskan lembaganya membekali siswa dengan pokok-pokok agama Islam seperti baca tulis A1-Qur'an.

"SDN 01 Lemito bukan madrasah ibtidaiyah yang secara khusus diperuntukkan membekali siswa didik lebih banyak mendalami pelajaran yang berhubungan dengan ajaran Islam. Namun hal itu tidak mengendorkan semangat kami dalam mendidik anakanak mengenal baca tulis al-Qur'an. Kami memprogramkan praktek baca tulis al-Qur'an melalui kegaiatan ekstrakurikuler keagamaan" 28

Ekstrakurikuler baca tulis al-Qur'an pada siswa dapat membantu perkembangan berpikirnya dalam mempelajari al-Qur'an. Apabila kegiatan ini dilakukan terus menerus akan menambah pengetahuan pada siswa tentang al-Qur'an, dengan cara mebaca da menulis serta mendengarkan bacaan al-Qu'an. Dalam mengenalkan alQur'an dapat dilakukan dengan perlihatkan al-Qur'an kepada siswa sebelum mereka mengenal buku-buku lain, apalagi buku-buku yang menarik seperti komik dan majalah. Mengenalakan al-Qur'an juga bisa dilakukuan dengan mengenalkan terlebih dahulu huruf-huruf hijaiyyah, apabila itu dilakukan terus menerus akan membuat siswa ingin mengetahuinya lebih jelas, sehingga bisa membantu mempelancar dalam mengenal al-Qur'an. SDN 01 Lemito dalam mengajarkan bacaan dan tulisan alQur'an pada siswa tidak dengan langsung tetapi melalui tahap-tahap yang menarik, agar siswa tidak mempunyai rasa bosan dalam mempelajari al-Qur'an, walaupun banyak kesulitan dalam mempelajari al-Qur'an, terlebih dahulu menerangkannya agar siswa paham dengan isi al-

\footnotetext{
${ }^{27}$ Marni Lahay, Kesenian, SDN 01 Lemito Kabupaten Pohuwato. Wawancara: 16 Agustus 2019

${ }^{28}$ Asrin Umar, Guru kelas II SDN 01 Lemito Kabupaten Pohuwato. Wawancara : 16 Agustus 2019
} 
Qur'an, dengan itu tidak akan membuat anak-anak kesulitan dalam mempelajarinya.

$$
\text { Fungsi pendidikan al-Qur'an terhadap }
$$

perkembangan kognitif dan afektif siswa secara umum ialah meningkatkan perkembangan moral siswa dan kemampuan siswa untuk mendengarkan dan menghafalakan ayat al-Qur'an, sehingga secara tidak langsung hal tersebut akan mengembangkan daya ingatnya dan pemahamannya serta meningkatkan daya pikirnya untuk mampu memecahkan suatu persoalan yang dihadapi baik secara akademik dan non akademik, selain itu juga mendorong kepada anak-anak untuk mempelajari AlQur'an.

$\begin{array}{lccr}\text { "Pengaruh pendidikan } & \text { al-Qur'an terhadap } \\ \text { perkembangan } & \text { siswa secara } & \text { kognitif ialah } \\ \text { mempengaruhi } & \text { daya ingat, pemahaman dan }\end{array}$
pemecahan masalah anak-anak. Jika ditinjau secara afektif pendidikan al-Qur'an akan berpengaruh terhadapa kondisi moralnya, sehingga siswa akan mampu berorientasi sebagaimana seseorang harus bersikap, dan siswa akan terbiasa berperilaku sosial yang baik. Itulah sebabnya SDN 01 Lemito menjadikan baca tulis al-Qur'an sebagai bagian dari praktek ekstrakurikuler" 29

Selain mengajarkan bacaan ayat-ayat al-Qur'an dengan menghafal, mendengarkan, memperkenalkan SDN 01 Lemito juga mengajarkan hukum-hukum al-Qur'an dan maknanya karena keduanya sama pentingnya.

"Keduannya merupakan satu rangkaian yang tidak dapat terpisahkan sehingga materi tersebut penting untuk dipelajari agar anak-anak bisa memahaminya lebih jelas. Maka dari itu mengajarkan al-Qur'an bukan hanya bacaan tetapi juga hukum-hukumnya dan maknanya, adapun cara mengajarkannya, diantaranya mengajarkan tajwid, yang didasarkan pada hukum bacaan yang disusun oleh ulama, dan ini tidak bisa ditinggalkan karena membaca al-Qur'an sesuai

\footnotetext{
${ }^{29}$ Yunizar Tangahu, Kepala SDN 01 Lemito Kabupaten Pohuwato. Wawancara : 16 Agustus 2019

64 Isma Tangahu
} 
dengan kaidah ilmu tajwid bahkan dapat membantu anak-anak dapat membaca Al-Qur'an denagn benar, ${ }^{30}$

c. Peringatan hari-hari besar Islam

Tidak hanya melaksanakan kegiatan di luar jam belajar yang bernuansa akademik, sekolah juga menyelenggarakan ekstrakurikuler yang bernilai sosial keagamaan. Salah satu kegiatan ekstrakurikuler yang dilaksanakan oleh sekolah adalah melaksanakan peringatan hari-hari besar Islam

Tujuan diadakannya peringatan dan perayaan hari besar Islam adalah melatih peserta didik untuk selalu berperan serta dalam upaya-upaya menyemarakkan syiar Islam dalam kehidupan masyarakat melalui kegiatankegiatan yang positif dan bernilai baik bagi perkembangan internal ke dalam lingkungan masyarakat yang lebih luas.

Pada hari jumat tanggal 13 September 2019 diadakanlah ceramah dalam rangka memperingati tahun baru Islam 1 Muharram 1441 Hijriah. Penulis mengikuti kegiatan tersebut secara langsung sambil mengawasi siswa yang antusias mengikuti acara yang dimlai sejak pukul 07.00 pagi.

Acara pertama dimulai dengan pembukaan oleh pimpinan sekolah lalu diikuti dengan pembacaan puisi oleh salah satu siswa setelah itu baru dimulailah ceramah. "Alhamdulillah pada saat mulainya ceramah sampai berakhir kegiatan berlangsung dengan tertib dan lancar tanpa kendala apapun, Insya Allah kami dapat menghayati pesan dari ceramah yang disampaikan oleh ustad tadi" 31

Setelah ceramah berakhir seluruh siswa langsung kembali ke kelas mereka masing-masing dan pembelajaran pada hari Jumat tersebut kembali berlangsung seperti biasa. Apa yang dilakukan oleh sekolah merupakan kegiatan positif yang dapat meningkatkan pemahaman siswa tentang sejarah bagaimana penetapan tahun baru Islam, menguatkan akidah serta bisa membentuk karakter mereka.

\footnotetext{
${ }^{30}$ Hirna Giasi, Guru Kelas I SDN 01 Lemito Kabupaten Pohuwato. Wawancara : 16 Agustus 2019

${ }^{31}$ Suciwati Ilhude, Siswa kelas VI SDN 01 Lemito Kabupaten Pohuwato. Wawancara : 10 Oktober 2019
} 


\section{d. Pesantren Kilat}

Pesantren kilat merupakan salah satu kegiatan ekstrakurikuler yang diselenggarakan pada waktu bulan puasa Ramadhan. Pesantren kilat yang diisi dengan berbagai bentuk kegiatan keagamaan seperti buka bersama, pengkajian dan diskusi agama atau kitab-kitab tertentu, shalat terawih berjamaah, tadarus al-Qur'an dan lain-lain.

"Kami sangat berharap dengan adanya pembinaan dari sisi kerohanian melalui kegiatan pesantren kilat dapat membangun mental yang baik bagi setiap perserta didik. Agar mereka dapat membentengi diri dari pengaruh-pengaruh buruk akibat dari perkembangan zaman" 32

Ekstrakurikuler keagamaan di SDN 01 Lemito memungkinkan peserta didik dapat membiasakan mereka menjalani kehidupannya sebagaimana tuntunan Islam, sehingga dengan mudah dapat membentuk pribadi yang islami.

Sifat Kepemimpinan Kepala Sekolah dalam Mengembangkan Kegiatan Ekstrakurikuler Keagamaan

Pemimpin, termasuk di dalamnya kepala sekolah, mempunyai tanggung jawab baik secara fisik maupun spiritual terhadap keberhasilan aktivitas kerja dari yang dipimpin, sehingga menjadi pemimpin itu tidak mudah dan tidak akan setiap orang mempunyai kesamaan di dalam menjalankan kepemimpinannya.

Pemimpin memiliki keterampilan yang mungkin tidak selalu mudah untuk didefinisikan. Tetapi kita tahu sifat kepemimpinan seseorang ketika kita melihatnya. Sebagai hasilnya, mereka yang memiliki kemampuan kepemimpinan berbagi beberapa kualitas yang membuat mereka sukses dan menonjol. Sebagai contoh, mereka tetap memegang teguh prinsip dan nilai yang jelas tentang diri mereka sendiri, orang-orang dalam kehidupan mereka, dan tempat mereka.

Para pemimpin dari semua lapisan kehidupan yang

\footnotetext{
${ }^{32}$ Yunizar Tangahu, Kepala SDN 01 Lemito Kabupaten Pohuwato. Wawancara :12 Oktober 2019
} 
melangkah dalam komunitas, kota, dan tempat kerja untuk membantu orang lain dan mengubah kehidupan juga membuat dampak yang lebih besar pada siapa yang mereka layani sebagai pemimpin. Sama seperti sekolah lainnya, di SDN 01 Lemito kabupaten Pohuwato, kepala sekolah merupakan pemimpin bagi masyarakat sekolah baik guru, karyawan, dan siswa. Sebagai pemimpin, maka perilaku kepala sekolah akan berpengaruh terhadap perilaku masyarakat sekolah. Perilaku positif yang selama ini ditunjukkan kepala sekolah memacu guru dan karyawan memberikan perilaku yang Peran kepemimpinan kepala sekolah menjadi sangat penting dalam mengembangkan kegiatan ekstrakurikuler keagamaan. Keberhasilan kepemimpinan itu sebagian besar ditentukan oleh sifat-sifat kepribadian tertentu, misalnya inovatif, harga diri, prakarsa, kecerdasan, kelancaran berbahasa, kreatifitas termasuk ciri-ciri fisik yang dimiliki seseorang.

"Yang paling menonjol dari kepala SDN 01 Lemito adalah sifatnya yang energik selama memimpin. Beliau punya kemampuan yang sangat efektif untuk membuat orang lain menerima gagasan-gagasannya yang inovatif. Beliau punya kemampuan untuk meyakinkan, sehingga kami percaya dan mengikuti gagasan tersebut secara serius" ${ }^{, 3}$

Kepala sekolah perannya sangat penting dalam membantu guru dan muridnya. Didalam kepemimpinannya kepala sekolah mampu memahami, mengatasi dan memperbaiki kekurangan-kekurangan yang terjadi di lingkungan sekolah. Selain itu ia juga memiliki kemampuan mengembangkan hal terkait dengan kegiatan belajar siswa, baik yang intrakurikuler maupun ekstrakurikuler.

"Khusus untuk kegiatan ekstrakurikuler, Kepala SDN 01 Lemito sangat intens memantau pelaksanaannya. Beliau tak henti berkoordinasi dengan guru-guru sejak perencanaan, pengorganisasian, komunikasi hingga sampai pengawasan ekstrakurikuler keagamaan di

\footnotetext{
${ }^{33}$ Ilham Hambali, Ketua Komite SDN 01 Lemito Kabupaten Pohuwato. Wawancara, 12 Oktober 2019
} 
sekolah ini" ${ }^{34}$

Kepala sekolah, Yunizar Tangahu, S.Pd. mempunyai sifat-sifat kepemimpinan yang mampu mengembangkan kegiatan ekstrakurikuler keagamaan. Selama melakukan penelitian di SDN 01 Lemito penulis melihat secara langsung bagaimana Yunizar Tangahu, berhasil mengorganisir pelaksanaan ekstrakurikuler keagamaan di sekolah tersebut. Dari kegiatan praktek ibadah, baca tulis Alquran hingga pesantren kilat berjalan baik hingga mendapatkan apresiasi dari orang tua siswa.

"Kami orang tua siswa sangat mengapresiasi upaya sekolah khususnya ibu Yunizar Tangahu yang telah membuat kegiatan religius sehingga anak-anak kami menjadi terbiasa melakukan kegaiatan yang bernuansa Islam. Manfaatnya sungguh sangat besar bagi perilaku dan kebiasaan anak setiap hari”,35

Berikut ini sifat-sifat kepemimpinan yang dimiliki kepala sekolah dalam mengembangkan kegiatan ekstrakurikuler keagamaan.

a. Energik dalam memimpin

Pengembangan ekstrakurikuler kegamaan yang dilakukan oleh kepala SDN 01 Lemito bukanlah pekerjaan yang mudah. Program ini membutuhkan kekuatan fisik karena dilakukan di tengah atau setelah pelajaran jam belajar usai. Melakukan dua proram sekaligus dalam sehari penuh tentu saja membutuhkan kekuatan fisik lebih dari biasanya. Pengembangan ekstrakulier merupakan program jangka panjang yang dilakukan melalui tahapan perencanaan, pengorganisasian, komunikasi dan pengawasan. Tahapan-tahapan pengembangan ini tentu saja membutuhkan waktu yang tidak singkat serta memerlukan tenaga ekstra keras.

"Hal yang jarang dimiliki oleh semua orang adalah kemampuan fisik dalam melaksanakan program. Apalagi jika program tersebut dengan perencanaan, pengoganisasian, komunikasi dan pengawasan yang matang. Tentu saja tahapan-tahapan itu membutuhkan

\footnotetext{
${ }^{34}$ Hirna Giasi, Guru Kelas I SDN 01 Lemito Kabupaten Pohuwato. Wawancara: 28 Oktober 2019

${ }^{35}$ Ferawati Umar, Orang tua siswa SDN 01 Lemito Kabupaten Pohuwato, Wawancara: 28 Oktober 2019 
pikiran dan tenaga yang besar. Nah, justeru kepala sekolah memenuhi kriteria dalam mengiplementasikan program yang butuh tahapan panjang tadi. Beliau sangat energik menyelenggarakan kegiatan ekstrakurikuler keagamaan di sekolah. Bayangkan, ibu Yuni, demikian kami biasa menyapa beliau, sejak pagi hingga sore berkutat dengan kegiatan intra maupun ekstrakurikuler. Semua itu beliau jalani tanpa mengeluh sedikitpun. Ibu Yuni punya kekuatan yang tidak kami miliki. Tidak heran jika guru-guru disini mengakui sifat kepemimpinan yang begitu power full, 36

Untuk tercapainya kepemimpinan yang baik diperlukan energi yang baik pula, jasmani maupun rohani. Seorang pemimpin harus sanggup bekerja dalam jangka panjang dan dalam waktu yang tidak tertentu. Sewaktuwaktu dibutuhkan tenaganya, ia harus sanggup melaksanakannya mengingat kedudukannya dan fungsinya. Karena itu kesehatan fisik dan mental benar-benar diperlukan bagi seorang pemimpin.

Seorang pemimpin dianggap penting dalam suatu pendidikan, sebab pemimpin harus mampu untuk menggerakkan pelaksanaan pendidikan, sehingga tujuan pendidikan yang telah ditetapkan dapat tercapai secara efektif dan efisien.Dalam memangku jabatan pemimpin pendidikan yang dapat melaksanakan tugas-tugasnya dan memainkan peranannya sebagai pemimpin yang baik, maka dituntut beberapa persyaratan jasmani, rohani dan moralitas yang baik, bahkan persyaratan sosial ekonomis yang layak.

Hal tersebut akan menjadi faktor penentu yang membedakan antara seseorang pemimpin dengan yang bukan pemimpin. Sifat-sifat pokok itu biasanya meliputi kondisi fisik (energik, tegap, kuat), latar belakang sosial (berpendidikan dan berwawasan luas), dan kepribadian (adaptif, emosistabil, dan lain-lain). Adanya berbagai sifat dalam kepemimpinan menunjukkan bahwa kepemimpinan bukan hanya menentukan kesanggupan dan

\footnotetext{
${ }^{36}$ Sopiah A. Harun, Guru kelas VI SDN 01 Lemito Kabupaten Pohuwato, Wawancara: 28 Oktober 2019
} 
kemauan saja, tetapi lebih lagi kemampuan dan kesediaan dalam pemimpin. Dengan demikian, pandangan teori sifat dalam kepemimpinan juga dibutuhkan oleh seorang pemimpin yang ingin meningkatkan kemampuan dan kecakapannya dalam memimpin

\section{b. Cerdas Mengendalikan Emosi}

Kepala SDN 01 Lemito kabupaten Pohuwato dikenal paling bagus dalam mengendalikan emosinya dalam tugas kesehariannya di sekolah. Ia dianggap seorang pemimpin yang baik karena jauh dari purbasangka, kecurigaan terhadap bawahan-bawahannya. Sebaliknya, disaat lain ia tegas, konsekuen dan konsisten dalam tindakantindakannya, percaya diri sendiri dan memiliki jiwa sosial terhadap bawahannya.

"Selama ini kegiatan ekstrakurikuler keagamaan pengelolaannya sudah berjalan sangat baik. Upaya tersebut bisa dilihat langsung dimana tahap-tahap perencanaan, pengorganisasian, komunikasi dan pengawasan sangat baik dikendalikan oleh kepala sekolah. Ini tentu saja hal itu tidak bisa dilepaskan dari kepemimpinan belaiu yang pandai menciptakan rasa nyaman di kalangan guru dan siswa. Beliau sangat hebat mengatur sehingga hampir-hampir tidak ada gesekan antara satu pegawainya dengan yang lain" 37

Menjadi pemimpin bukanlah persoalan mudah. Sebagai penentu keputusan dan panutan anak buahnya, seorang pemimpin harus memiliki keseimbangan kecerdasan intelektual dan kecerdasan emosi. Bahkan faktor kecerdasan intelektual hanya berperan 20 persen dalam kesuksesan karir seseorang. Selebihnya faktor kecerdasan emosi yang menentukan. Dengan begitu, selain pintar dalam hal akademis, seorang pemimpin juga harus bisa mengenali emosi, mengelola emosi, memotivasi diri sendiri, memiliki empati dan juga membina hubungan.

Hasil pantauan penulis menunjukan bahwa kepala sekolah sesungguhnya memang sangat cerdas

\footnotetext{
${ }^{37}$ Praity Yudhistira, Guru Penjas kelas VI SDN 01 Lemito Kabupaten Pohuwato, Wawancara: 28 Oktober 2019 
mengendalikan emosisnya. Selama beberapa pekan mengunjungi sekolah tersebut penulis belum sekalipun mendengar maupun melihat ia kehilangan kendali atas emosinya. Ia sangat mengetahui apa yang akan dilakukan saat behadapan dengan kondisi yang mudah memicu hilangnya kendali atas emosi terlebih dalam proses pelaksanaan kegiatan ekstrakurikuler

"Pemimpin itu harus mengetahui apa yang dirasakan oleh bawahan dan orang lain di sekitarnya. Menjadi pemimpin jangan sampai uring-uringan atau stress sendiri. Pemimpin harus mengenal baik emosinya. Dengan begitu, ia akan mudah mengelola emosi tersebut" 38

Menurutnya seorang pemimpin harus memiliki keseimbangan antara intelektual dan emosi. Karena percuma bila memiliki kepintaran dalam hal akademis, tetapi emosinya mudah meledak-ledak.

\section{c. Memotivasi Pribadi}

Bagian terpenting dari kesuksesan pelaksanaan ekstrakurikuler keagamaan di sekolah adalah peran yang dilakoni kepala sekolah selama melakukan pengawasan dan komunikasi dan mengorganisir prosesnya. Semua sifat kepemimpinan yang dimiliki kepala sekolah pada akhirnya mengerucut pada bagaimana ia mampu melahirkan sifat-sifat kepemimpinan tersebut.

"Pemimpin yang energik dan cerdas mengendalikan emosi pasti ada sesuatu yang mempengaruhi dirinya sendiri. Saya ingin mengatakan bahwa siapapun bias menajdi pemimpin yang punya sifat kepemeimpinan yang benar asalkan mampu memotivasi dirinya sendiri. Ini saya lakukan setiap saat. Ada-ada saja momentum yang saya jadikan embrio mengangkat semangat saya agar semangat kerja tetap terjaga" 39

Pekerjaan sebagai seorang pemimpin memang mengharuskannya untuk terus memotivasi bawahan. Tetapi pasti saat seseorang termasuk pemimpin merasa stagnan dan seakan tidak memiliki mimpi dalam karir lagi

\footnotetext{
${ }^{38}$ Yunizar Tangahu, Kepala SDN 01 Lemito Kabupaten Pohuwato. Wawancara: 29 Oktober 2019

${ }^{39}$ Yunizar Tangahu, Kepala SDN 01 Lemito Kabupaten Pohuwato. Wawancara: 29 Oktober 2019
} 
dan bahkan kehilangan motivasi. Bila seorang pemimpin terlena dengan semua prestasi sebelumnya, maka ia akan kehilangan keunggulan dan merasa tidak termotivasi untuk terus mengembangkan diri.

"Saya merasa bahwa semua program yang saya lakukan terutama kegiatan ekstrakurikuler keagamaan di sekolah telah terealisasi dengan baik. Namun hal tersebut tidak lantas membuat saya puas dan berhenti untuk mengembangkan program penting lainnya bagi kemajuan sekolah ini. Untuk itulah saya terus memotivasi diri saya sendiri agar tidak terlena dengan keberhasilan yang ada. Bahkan saya berencana akan membuat kegiatan ekstrakurikuler yang berbasis digital. Nantinya kegiatan ekstrakurikuler di sekolah bisa diakses langsung oleh sekolah mana saja yang terjangkau oleh jaringan, demikian pula sebaliknya" 40

Bisa jadi pemimpin adalah satu-satunya pusat kekuatan antusiasme bagi bawahan namun apa yang terjadi ketika semangat pemimpin tersebut menghilang dan ia merasakan semua semangatnya memudar. Menurut penulis, tidak akan ada yang tahu dan mau mengerti apalagi ingin menjadi yang pertama memotivasi pemimpin tersebut selain dirinya sendiri. Pemimpin adalah motivasi terbesar bagi kepemimpinannya.

Kepala SDN 01 Lemito dalam pandangan bawahannya adalah sosok yang tidak pernah patah semangat dalam mengelola kegiatan ekstrakurikuler keagamaan.

"Kadang-kadang kami kehilangan semangat saat kegiatan ekstrakurikuler yang sekian lama kami rencanakan tiba-tiba harus ditunda atau bahkan mendapatkan penolakan dari banyak kalangan. Contohnya Pesatren Kilat. Ternyata kegiatan tersebut disoroti oleh banyak kalangan. Tidak sedikit orang tua siswa yang enggan mengijinkan anaknya mengikuti kegiatan tahunan tersebut. Lebih dari itu, bahkan ada oknum yang menganggap bahwa kegiatan keagamaan tersebut hanya membuang waktu, tenaga,

\footnotetext{
${ }^{40}$ Yunizar Tangahu, Kepala SDN 01 Lemito Kabupaten Pohuwato. Wawancara: 01 November 2019
} 
pikiran anak-anak. Ekstrimnya lagi, ada menuduh jika pesantren kilat cuman ajang bagi sekolah untuk ambil untung. Tapi kepala sekolah justeru kelihatan bersemangat menghadapinya. Ia mengatakan kepad kami bahwa tugas mulia ini tidak boleh gagal hanya karena oknum yang belum memahami substansi yang terkandung di dalamnya "41

\section{d. Komunikatif}

Sifat kepemimpinan kepala SDN 01 Lemito dalam mengembangkan kegiatan ekstrakurukuler keagamaan salah satunya adalah komunikatif. Kepala sekolah, Yunizar Tangahu memang memiliki kemahiran dalam menyampaikan gagasan baik secara lisan maupun tulisan. Dalam beberapa sesi wawancara dengan penulis, kepala sekolah sangat komunikatif dan cepat memahami serta merespon setiap lawan bicaranya mengajukan pertanyaan atau pernyataan.

"Ibu Yunizar sangat komunikatif. Setiap yangbeliau sampaikan cepat sekali kami pahami. Beliau juga pandai mendalami maksud yang disampaikan oleh lawan bicaranya. Tidak heran jika setiap perintahnya langsung dikerjakan" 42

Komunikatif sangat penting bagi kepala sekolah untuk mendorong maju bawahan, memberikan atau menerima informasi bagi perkembangan ekstrakurikuler keagamaan. Tanpa adanya jalinan komunikasi yang baik dan benar besar kemungkinan semua tahapan di dalam kegiatan tersebut tidak akan dapat berjalan dengan maksimal dan sesuai dengan yang telah direncanakan. Kemampuan komunikasi yang baik akan sangat membantu semua proses yang ada dalam suatu program. Kepala sekolah membutuhkan kemampuan komunikasi yang baik terutama saat kegiatan berjalan kurang lancar.

"Penting bagi saya sebagai pemimpin untuk membangun komunikasi. Dengan komunikasi tersebut saya dapat mempengaruhi orang untuk membawa perubahan menuju visi, atau masa depan yang

\footnotetext{
${ }^{41}$ Sopiah A. Harun, S.Pd, Guru Kelas VI SDN 01 Lemito Kabupaten Pohuwato. Wawancara: 02 November 2019

${ }^{42}$ Praity Yudhistira, S.Pd Guru Penjas kelas VI SDN 01 Lemito Kabupaten Pohuwato, Wawancara: 02 November 2019
} 
diinginkan, bagi sekolah ini. Saya berkomunikasi untuk berbagi visi dengan orang lain, menginspirasi dan memotivasi mereka untuk berjuang menuju visi, dan membangun nilai dan kepercayaan yang memungkinkan hubungan kerja dan pencapaian tujuan yang efektif khususnya dalam pelaksanaan kegiatan ekstrakurikuler keagamaan di sekolah"43

Di Lembaga pendidikan kepala sekolah adalah sebagai komunikator. Kepala sekolah yang efektif pada umumnya memiliki kemampuan komunikasi yang efektif sehingga sedikit banyak akan mampu merangsang partisipasi orang-orang yang dipimpinnya. Kepala sekolah bisa dilihat sebagai juara komunikasi. Kepala sekolah menggunakan komunikasi untuk menginspirasi dan menyatukan orang-orang di sekitar pada tujuan dan identitas umum dan untuk memastikan bahwa visi dan strategi dipahami dan diterima secara mendalam oleh bawahannya.

Sifat komunikatif dalam kepemimpinan kepala sekolaj juga membentuk bagaimana orang memikirkan pekerjaan dan lembaganya. Kepala sekolah yang baik tidak hanya menggunakan komunikasi untuk menginspirasi orang dengan sebuah visi dan menanamkan nilai-nilai yang diperlukan untuk mencapainya, mereka juga berkomunikasi untuk membantu orang memahami tujuan kerja mereka yang lebih besar. Pemimpin komunikatif tampak dan secara simbolis terlibat dalam kegiatan berbasis komunikasi.

\section{Kesimpulan}

Ekstrakurikuler keagamaan di sekolah tersebut bersifat rutin dan mencakup kewajiban partisipasi bagi seluruh siswanya. Pelaksanaan program ekstrakurikuler keagamaan di SDN 01 Lemito berbeda variasinya dengan beberapa sekolah pada umumnya hal ini terjadi karena ditentukan oleh kemampuan guru, siswa, dan kemampuan sekolahnya. Bentuk kegiatan ekstrakurikuler keagamaan di Sekolah terdiri dari; 1) Praktek Ibadah 2) Baca Tulis Alquran 3) Peringatan hari besar Islam. Sifat-sifat

\footnotetext{
${ }^{43}$ Yunizar Tangahu, S.Pd, Kepala SDN 01 Lemito Kabupaten Pohuwato. Wawancara: 01 November 2019
} 
kepemimpinan kepala sekolah dan mengembangkan kegiatan ekstrakurikuler adalah: energik dalam memimpin, cerdas mengendalikan emosi, memotivasi pribadi, komunikatif.

\section{Daftar Pustaka}

A. Dale Timple, The Art And Scicien of Business Management Leadership, Jakarta, PT. Elex media kompotindo, Gramedia, 2002,

Ahmad Musthofa al-Maraghi, Tafsir al-Maraghi, juz III terjemahan Imam Cahyo, Beirut: Dar Ihyae wal Turots al-Azali, tt, 2011 ,

Alim Sumarno, Caulsalitas Komparatif, Jakarta: Unesa, 2012

Ardy Wiyani Novan, Psikologi Perkembangan Anak Usia Dini, Yogyakarta: Gava Media, 2014.

Badrudin, Dasar-dasar Manajemen, Cetakan kedua, Bandung: Alfabeta, 2014.

C. Turney, Dalam Martinis Yamin dan Maisah, Kepemimpinan dan Manajemen Masa Depan, Bogor: IPB Press, 2010.

Danim, Sudarwan, Kepemimpinan Pendidikan, Kepemimpinan Jenius, Etika, Perilaku Motivasional, dan Mitos, Bandung: Alfabeta, 2010.

Danim, Sudarwan, Motivasi Kepemimpinan \& Efektivitas Kelompok, Jakarta: PT Rineka Cipta, 2004.

E.Mulyasa, Menjadi Guru Profesional, Bandung: PT. Remaja Rosdakarya, 2009.

Fattah, Kepemimpinan Sebuah Keniscayaan, Jakarta: Titian Ilmu, 2004.

George R. Terry, Asas-asas Manajemen, cetakan ketujuh, Bandung: PT Alumni, 2010.

Hasibuan, Malayu S.P, Manajemen Sumber Daya Manusia, Jakarta: PT Bumi Aksara, 2010.

Hermawan Warsito, Pengantar Metodologi Penelitian, Buku Panduan Mahasiswa, Jakarta: PT. Gramedia Utama, 2014.

Ibnu Hadjar, Dasar-Dasar Metodologi Penelitian Kuantitatif dalam Pendidikan, Jakarta: Raja Grafindo Persada, 1996. 
Imam Cahyo, Kepemipinan Kepala Sekolah, Jakarta: Pustaka Abadi, 2014.

James M., Black dalam Sadili, Samsudin, Manajemen Sumber Daya Manusia. Bandung: Pustaka Setia, 2006.

Miftah Thoha, Kepemimpinan dan Manajemen, Divisi Buku Perguruan Tinggi, Jakarta: PT. Raja Grafindo Persada, 2010.

Moleong, Metodologi Penelitian Kualitatif, akarta: Rineka Cipta, 2014.

Popi Sopiatin, Manajemen Belajar Berbasis Kepuasan Siswa, Bogor: Ghalih Indonesia, 2014.

Siagian, P. Sondang, Pemimpin dan Kepemimpinan Kepala Sekolah, Jakarta: Gunung Agung, 2001.

Suryosubroto, Proses Belajar Mengajar di Sekolah, Jakarta: Titian Pustaka, 2014.

Wahjosumidjo, Kepemimpinan Kepala Sekolah, Tinjauan Teori dan Permasalahannya, Jakarta: Raja Grafindo Persada, 2012.

Wahyudi, Kepemimpinan Kepala Sekolah dalam Organisasi Pembelajaran. Bandung: Alfabeta, 2009. 